\title{
US exchange scheme offers a taste of Europe
}

\section{Quirin Schiermeier, Munich}

The flow of young European researchers into the United States may look like a deluge, with a mere trickle in the opposite direction. But the US National Science Foundation (NSF) hopes to address the imbalance through a scheme that will twin its research centres with similar institutions abroad.

The NSF's informal "centre-to-centre" project will encourage the university-based centres funded by the foundation in the United States to identify potential research partners abroad. The NSF hopes that this will encourage young American researchers to venture across the Atlantic.

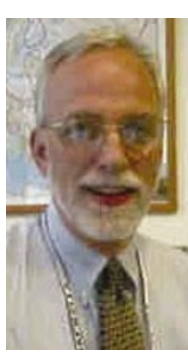

David Schindel, head of the NSF's European office in Paris, announced the scheme at a talk given last month to a group of officials of European research agencies and institutions at the European Commission in Brussels.

On the basis of an eDavid Schindel: mail survey of European exchange envoy. funding agencies and universities, Schindel is compiling a database of around 600 research centres with structures that are similar to those supported by the foundation in the United States. The NSF has begun to disseminate the information to the heads of 250 US centres, encouraging them to match themselves with appropriate partners.

The NSF-funded centres, which carry out basic research in a variety of disciplines, each receive annual support of between $\$ 500,000$ and $\$ 5$ million from the foundation. Potential European partners include Germany's International Max Planck Research Schools, the Interdisciplinary Research Collaborations funded by the UK Research Councils, and the Centres of Excellence funded by the European Union in central and eastern Europe.

The NSF's Office of International Science and Engineering will finance travel costs and introductory workshops aimed at initiating contacts, says Rose Gombay, a programme manager for western Europe who is based at the NSF's headquarters in Arlington, Virginia. Further funding will be made available if joint research activities materialize, she says.

The main goal of the new initiative is to encourage postdoctoral fellows and $\mathrm{PhD}$ candidates in the United States to spend some time overseas, says Schindel.

"There is no doubt that transatlantic traffic of young researchers is primarily one-way," Schindel explains. "We would like many more young US researchers to travel to and work in Europe and elsewhere."

The number of young American researchers working in Europe is low — there are fewer than 300 US postdocs in Germany, for example. On the other hand, $40 \%$ of the 20,000 postdocs in the United States are of non-US origin.

The NSF acknowledges the lack of mobility of young scientists in the United States. "There is a strong cultural barrier, and there is the sheer size of the US system that feeds the belief that it is not necessary to go abroad," says Mark Suskin, a programme manager at the NSF's international office. "However, international experience is indispensable for today's scientific workforce."

Fostering exchanges for young researchers

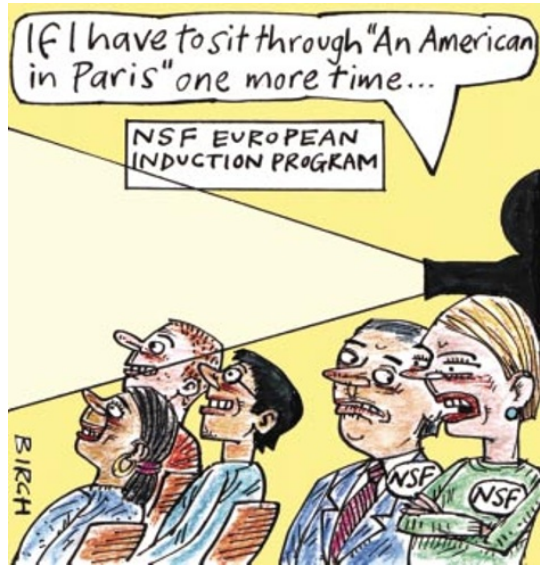

is already a priority for the NSF's international office, says Suskin. He hopes that the new scheme, and the preliminary work carried out by Schindel, will give an "extra push" to mobility. "We encourage all heads of centres in the United States and Europe to get in touch on their own, and then come to the NSF for some funding," Suskin says.

The use of established centre infrastructures, and the mentorship that they can provide, is essential to counter young scientists' concerns about possible career problems when re-entering the system, says Philip Bucksbaum, an associate director of the Center for Ultrafast Optical Science at the University of Michigan in Ann Arbor.

Funded by an NSF pilot programme, Bucksbaum's centre has, for the past five years, exchanged postdocs with the French Ecole Polytechnique's Laboratory of Optical Applications. The arrangement has included annual bilateral miniconferences between the centres.

"It has worked very well — there were no problems at all with research careers," says Bucksbaum. He calls on young researchers to make use of the opportunities for mobility that such partnerships can present. In career development, "the plusses of a stay abroad will always outweigh the minuses", he says. www.nsf.gov/home/int/europe

\section{France hails milestone in start-ups}

\section{Sally Goodman, Paris}

Entrepreneurship is finally making a mark on French public research, according to at least one important measure.

Last week the CNRS, France's main basic research agency, celebrated the creation of the 100th start-up company by its researchers - three years after a law was passed allowing such activity for the first time.

"The 1999 law is really behind the change of mentality that we are seeing in French researchers," says Nicolas Mouz, a structural biologist who helped set up Protein'eXpert, a biotechnology company, while on sabbatical from a CNRS laboratory in Grenoble.

The law, which was championed by the research minister at the time, Claude Allègre, opened the door for researchers working in public universities and research agencies to run or own companies built on their research findings. France was later than most of its competitors in allowing publicly funded researchers to do this, and the law's supporters thought that this was constraining innovation in biotechnology and other sectors. The French law also provided around $\mathbf{8 0}$ million euros (US\$80 million) to help support such companies.

Geneviève Berger, director general of the CNRS, says that the fostering of these small companies remains a top priority for the agency. It now aims to spin off at least $\mathbf{5 0}$ more companies each year from its laboratories, most of which are located in universities. The entrepreneurial culture needs to extend even further into the laboratories, she says, until researchers "are prepared to accept failures".

But Tristan Rousselle, Protein'eXpert's chief executive, says that more needs to be done to pick up on innovations with potential, and to overcome reservations about commercial activity that, he says, still exist at some CNRS laboratories. "The system still relies on resourceful researchers finding ways to promote their own projects," he says.

Researchers can expect France's new centre-right government to push hard for more business start-ups. Research minister Claudie Haigneré says she intends to reinforce her ministry's support for new companies, and the government is also expected to implement tax breaks for businesses that do research. 